九州大学学術情報リポジトリ

Kyushu University Institutional Repository

\title{
Determinants of Biogas Adoption in Manure Management of Vietnamese Household Pig Production : A Case Study in Tien Lu District, Hung Yen Province
}

\section{Ly, Nguyen Thi}

Laboratory of Agricultural and Farm Management, Department of Agricultural and Resource Economics, Faculty of Agriculture, Kyushu University

Nanseki, Teruaki

Laboratory of Agricultural and Farm Management, Department of Agricultural and Resource Economics, Graduate School of Bioresource and Bioenvironmental Sciences, Faculty of Agriculture, Kyushu University

Chomei, Yosuke

Laboratory of Agricultural and Farm Management, Department of Agricultural and Resource Economics, Graduate School of Bioresource and Bioenvironmental Sciences, Faculty of Agriculture, Kyushu University

https://doi.org/10.5109/1543430

出版情報: 九州大学大学院農学研究院紀要. 60 (2)，pp.577-581，2015-09-18. Faculty of Agriculture, Kyushu University

バージョン：

権利関係 : 


\title{
Determinants of Biogas Adoption in Manure Management of Vietnamese Household Pig Production: A Case Study in Tien Lu District, Hung Yen Province
}

\author{
Nguyen Thi LY' ${ }^{1}$, Teruaki NANSEKI* and Yosuke CHOMEI \\ Laboratory of Agricultural and Farm Management, Department of Agricultural and Resource Economics, \\ Graduate School of Bioresource and Bioenvironmental Sciences, Faculty of Agriculture, \\ Kyushu University, Fukuoka 812-8581, Japan \\ (Received May 8, 2015 and accepted May 19, 2015)
}

\begin{abstract}
Although biogas technology is one of the useful ways managing the animal manure to reduce environmental problems in rural area, many Vietnamese households that produce pigs still do not apply biogas digesters. This study aim to investigate the main factors contributing to biogas adoption in household pig production based on primary data collected in Tien Lu district, Hung Yen province in Vietnam and the use of Logit regression. The empirical results highlighted that socioeconomic characteristics of household pig productions were differed between biogas adoption group and biogas non-adoption group among them, including household heads' membership status (joined in farmer groups), training and education, medium and large farm size. Moreover, the results suggested that the probability of biogas adoption of household pig production increases with an increase of household heads' schooling years and households' income except for a case that when the former is higher than 10.5 or when the latter is more than 192.8 million VND. Also this probability increase with household heads are memberships and with large household farm size. Educational and awareness programs on the merits of biogas digester, particularly via the channels among farmers should be implemented. Furthermore, financial program should be offered to farmers especially to low income households.
\end{abstract}

Key words: Biogas adoption, household pig production, Logit Model, manure management, Vietnam

\section{INTRODUCTION}

Livestock production is considered as a main Vietnamese agricultural sector and contributes to improving the livelihood of farmers in rural area. The gross domestic product of livestock production contributes to a $26.8 \%$ of agricultural gross product domestic in 2013 (GSO, 2013) but this number will be predicted to over $42 \%$ by 2020 (Vietnamese Prime Minister, 2008). However, along with this development, their negative impacts on the environment are air, soil and water pollution by waste, especially manure from pig production. Thus, the management of animal manure sources is one of the biggest challenges that pig production in Vietnam is facing. According to Vu et al. (2007), slurry, liquid manure and solid manure are the three major manures on pig farming and not treatment with direct disposal to the field or to fishpond, composting, storage without treatment and biogas production are the four categories of manure management in pig production. Biogas production is perceived a good way to reduce some environmental problems in manure management as $\mathrm{Vu}$ et al. (2007) indicated that the spreading pathogens and noxious odor emission can be reduced by biogas digester.

Biogas technology is introduced in Vietnam since 2003 when the project of Biogas Program for the Animal Husbandry Sector in Vietnam (BPAHSV) have encour-

\footnotetext{
${ }^{1}$ Laboratory of Agricultural and Farm Management, Department of Agricultural and Resource Economics, Faculty of Agriculture, Kyushu University

* Corresponding author: nanseki@agr.kyushu-u-ac.jp
}

aged the construction of biogas digester by the cooperation between Livestock Production Department belonging to Ministry of Agricultural and Rural Development and Netherlands Development Organization (SNV) (BPAHSV, 2015b). The merits of biogas technology can be listed as creating a safety treatment of livestock waste and a clean environment, protecting infectious diseases, producing a cheap and clean energy for heating and cooking in households, improving the working environment for women, especially reducing deforestation in remote and mountainous areas (Tran et al., 2009).

Although biogas technology is one of the useful ways managing the animal manure to reduce environmental problems in rural area, many household pig production still does not apply biogas digester. With regard to the literature, there are some studies on biogas adoption in term of a renewable energy such as Mwirigi et al. (2009), Qu et al. (2013), and Walekhwa et al. (2009) but they have not focused on only pig farms where have a greatly potential participant in biogas production. Also in Vietnam, based on our knowledge there has been one study conducted by Thien Thu et al. (2012) who are concerning the comparison in manure management practices between adopted and non-adopted biogas pig farming but the authors only has pointed the reason why non-adopted pig farms do not adopt to biogas technology. They were only factors about farm characteristic including not enough money, number of animals, and land to install biogas digester, Thien Thu et al. (2012) has not indicated the farmer characteristics in their study. Thus, this study aims to find out the socioeconomic factors contributing to adopt biogas in manure 
management of household pig production.

\section{METHODOLOGY}

\section{Study sites and data collection}

The study was conducted in Tien Lu district, a typically agricultural district in Hung Yen province where located in the Red River Delta area, Vietnam. According to Hung Yen Department of Agricultural and Rural Development (HYDARD) (HYDARD, 2010), Tien Lu district has been planned to become one of two main largest pig production zones in Hung Yen province until 2020. Moreover, Hung Yen province is one of the provinces has been implementing the Biogas Program for the Animal Husbandry Sector in Vietnam since 2009 (BPAHSV, 2015a).

The field survey was conducted in Tien Lu district with 3 communes including Minh Phuong, Hung Dao and Di Che. The first two communes were selected randomly in five target communes that have been established concentrated livestock production of the district until 2020 (HYDARD, 2012) and the last commune was also selected randomly in the rest of 13 communes.

Primary data were gathered via personal and faceto-face interview using structured and semi-structured questionnaire from August to September, 2014. Totally 177 household farrow-to-finish pig producers have been interviewed randomly but only 161 were used to analysis.

\section{Empirical model}

To investigate the variety of factors contributing to the adoption of biogas in manure management of household pig production, logit model is used as Kabir et al. (2013) and Walekhwa et al. (2009).

The logit model is defined by Gujarati \& Handelshøyskolen (2011) as follows:

$$
\begin{aligned}
& \mathrm{Y}=\ln \left(\frac{P}{1-P}\right)=\beta \mathrm{X}+\mathrm{u} \\
& \text { with } \mathrm{P}=\frac{e \beta \mathrm{X}+\mathrm{u}}{1+e \beta \mathrm{X}+\mathrm{u}}
\end{aligned}
$$

Where $\mathrm{Y}$ is the dependent variable ( $\mathrm{Y}=1$ if household adopt biogas and 0 for otherwise). $\mathrm{P}$ is the probability of the biogas adoption, $\mathrm{X}$ are the independent variables (Table 1), $\beta$ are the parameters of the model, e is the base of the natural logarithm and $u$ is error term.

Before choosing the final model with independent variables in Table 1, there has been another two models trying with age variable which is usually used in adopting studies such as Kabir et al. (2013), Walekhwa et al. (2009), and Qu et al. (2013). The first model is a model with all of the independent variables in Table 1 and age variable and the second model is a model with the same variables in the first model but age variable changes from only age form to quadratic form with age and age squared (age2). Comparing among three above models by two conditions. The former condition is AIC indicator which model has the AIC indicator being as small as good. These AIC indicators for the current used model and the two comparing models are 196.4, 198.4 and 200.2, respectively. Thus, the used current model is the best. The latter condition are the Mc Fadden Pseudo R square. For three models, these indicators are $12.90 \%, 12.78 \%$ and $12.88 \%$, respectively. In addition, the age variable is not significant on both the non-choosing models.

\section{RESULTS AND DISCUSSION}

\section{Household pig production's socioeconomic charac- teristics}

Table 2 shows the mean and percentage values of all variables considered to have effects on adopting biogas in manure management in Vietnamese household pig production as well as the comparison of their differences between the biogas adoption group and the biogas nonadoption one.

On the one hand, the mean of schooling years of the household heads is 9.4 and it is 0.59 years higher in the adopted group than in the non-adopted one at significant $10 \%$. Moreover, in generally, 56\% of household heads has been trained in pig husbandry technique and $45 \%$ of them has been joined at least one organization such as co-operative organization, farmer association, women association, etc. where they can share and get information about production, market information, etc. In addition to, the proportions of the household heads in the adoption group have been trained and have been becoming the membership of the groups are significantly higher than in the non-adoption group at $17 \%$ and $16 \%$, respectively. It proves that the adoption group might be have better conditions to access to adopt biogas in manure management in pig production.

Table 1. Definition of factors used in Logit model

\begin{tabular}{lll}
\hline \multicolumn{1}{c}{ Variable } & \multicolumn{1}{c}{ Type } & \multicolumn{1}{c}{ Description } \\
\hline Training & Binary & Take 1 if household head is trainned in pig production and zero otherwise \\
Membership & Binary & Take 1 if household head is a member of any group and zero otherwise \\
Education & Continuous & Years of schooling of household head \\
Farm size & Categorical & Number of sow in 2014 ( Small =1; medium=2-3; Large $>=4)$ \\
Family member & Continuous & Number of family members joining in pig production \\
Income & Continuous & Total household income in 2013 (in million VND*) \\
\hline
\end{tabular}

Note: 1) The exchange rate in 2012 was $1 \mathrm{USD}=20,820 \mathrm{VND}$ 
On the other hand, $79 \%$ of households have medium and large scale in pig production but mostly they are medium scale keeping from 2-3 sows per year. In medium farm size, the rate of biogas non-adoption group is higher than that of biogas adoption group, 14\%. In contrast to this, in large farm size this rate is lower in the adoption group than in the non-adoption group with a $23 \%$ difference and there is no difference in this proportion between two groups in the small household size. Also it is found that there are no differences in number of family member joining in pig production and the total income of household between two groups. At this point, it is easy to see the household condition in adopting biogas system in manure management there are not many differences among households.

\section{Factors affecting biogas adoption in manure man- agement}

Results of binominal Logit Model are shown in Table 3. Firstly, the Likelihood Ratio (LR) Chi-square test was based on the assumption that it has at least one of the coefficients of the explanatory variables was not equal to zero. It is shown that LR Chi squared with 9 degree of freedom was 26.137 and it was significant at 5\%. It implies that the full model here is better than the model with only constant coefficient. Besides, to measure the goodness-of-fit of the logistic model Mc Fadden Pseudo-R2 was 12.90\%. Although Mc Fadden Pseudo-R2 in this study is relatively low, it is similar to the findings shown by Kabir et al. (2013) and Mwirigi et al. (2009) with Mc Fadden Pseudo-R2 being 14.6\% and 14.1\%, respectively. Moreover, Gujarati \& Handelshøyskolen (2011) emphasized that goodness of fit are the second importance measures in the binominal regression models.

Among the socio-economic factors, it is found that the education of household head (both education and education 2 at 5\% significant level), membership (at 10\% significant level), large farm size (at 5\% significant level) and total income of household (both income and income 2 , at $10 \%$ significant level) are statistically signifi-

Table 2. Descriptive statistics of factors used in Logit model

\begin{tabular}{|c|c|c|c|c|c|c|c|c|}
\hline \multirow{2}{*}{$\begin{array}{l}\text { Variable } \\
\text { Training }\end{array}$} & \multicolumn{2}{|c|}{$\begin{array}{c}\text { Biogas non-adoption } \\
\qquad(\mathrm{n}=52)(1)\end{array}$} & \multicolumn{2}{|c|}{$\begin{array}{c}\text { Biogas adoption } \\
(\mathrm{n}=109)(2)\end{array}$} & \multicolumn{2}{|c|}{$\begin{array}{l}\text { Difference } \\
(1)-(2)\end{array}$} & \multicolumn{2}{|c|}{$\begin{array}{l}\text { Total sample } \\
\quad(\mathrm{n}=161)\end{array}$} \\
\hline & Mean & $\mathrm{SD}$ & Mean & $\mathrm{SD}$ & & & Mean & SD \\
\hline Training & 0.4423 & 0.2515 & 0.6147 & 0.239 & -0.1724 & $* *$ & 0.5590 & 0.49806 \\
\hline Membership & 0.3462 & 0.2308 & 0.5046 & 0.2523 & -0.1584 & $* *$ & 0.4534 & 0.49938 \\
\hline Farm size Small & 0.2692 & 0.2006 & 0.1835 & 0.1512 & 0.0857 & & 0.2112 & 0.40942 \\
\hline Medium & 0.5577 & 0.2515 & 0.4128 & 0.2446 & 0.1448 & $* *$ & 0.4596 & 0.49992 \\
\hline Large & 0.1731 & 0.1459 & 0.4037 & 0.2429 & -0.2306 & $* * *$ & 0.3292 & 0.47139 \\
\hline Family member & 1.8462 & 0.5249 & 1.8165 & 0.1882 & 0.0296 & & 1.8261 & 0.54274 \\
\hline Income & 107.8316 & 89.51 & 125.5212 & 85.538 & -17.6895 & & 119.8078 & 86.9569 \\
\hline Education & 9.0000 & 11.216 & 9.5872 & 5.4484 & -0.5872 & $*$ & 9.3975 & 2.7071 \\
\hline
\end{tabular}

Note: 1$) * * * * *$ and $*$ indicate significant difference from $1 \%, 5 \%$ and $10 \%$, respectively

2) Own survey, 2014

Table 3. Results of Logit regression on biogas adoption in manure management

\begin{tabular}{|c|c|c|c|c|c|c|c|c|}
\hline Variable & Coeffici & ent & Standard Error & $\mathrm{z}$ & Prob. $|z|>Z^{*}$ & Odds ratio & \multicolumn{2}{|c|}{ Partial Effect } \\
\hline Constant & -3.25 & $* *$ & 1.55 & -2.10 & 0.04 & 0.04 & 0.4423 & \\
\hline Education2 & -0.03 & $* *$ & 0.01 & -2.36 & 0.02 & 0.97 & -0.01 & $* *$ \\
\hline Training & 0.44 & & 0.38 & 1.16 & 0.25 & 1.55 & 0.08 & \\
\hline Medium & -0.04 & & 0.45 & -0.08 & 0.94 & 0.97 & -0.01 & \\
\hline Large & 1.42 & $* *$ & 0.58 & 2.44 & 0.01 & 4.12 & 0.24 & $* * *$ \\
\hline Income & 0.01 & $*$ & 0.01 & 1.67 & 0.10 & 1.01 & 0.00 & $*$ \\
\hline Income2 & $.26 \mathrm{D}-04$ & $*$ & $.14 \mathrm{D}-04$ & -1.86 & 0.06 & 1.00 & $.47 \mathrm{D}-05$ & * \\
\hline
\end{tabular}

Note: 1) nnnnn.D-xx or $\mathrm{D}+\mathrm{xx}=>$ multiply by 10 to $-\mathrm{xx}$ or $+\mathrm{xx}$.

2) $* * *, * *$, and $*$ indicate significant difference from $1 \%, 5 \%$, and $10 \%$ respectively

3) Log likelihood function -88.216, Chi squared [ 9 d.f.] 26.137 Significance level .0019, McFadden Pseudo R-squared .1290

4) Sample size $=161$, Own survey 2014 
cant to contribute to the adoption of biogas in manure management of household pig production.

The level of education of household head has a quadratic form with an inverse $U$ shape. It means that the probability of building a biogas system is increasing with the household heads' level of education, but peaks at a level education of 10.5 years then that is decreasing. Moreover, the mean of schooling years of household heads in study area is 9.40 which household heads have just finished secondary school education. Thus, it means higher education household heads obtained, they are likely to be biogas adoption. However, when the level of education is higher, households tend not to be adoption. The reason might be at low education level, less educated household heads have less ability to access to the information of biogas production compared to their counterparts but at high education level, more educated household heads have more chances to access better technologies than biogas technology. This result is in line with the contrary results of Kabir et al. (2013) and Walekhwa et al. (2009). While Kabir et al. (2013) delighted that in Bangladesh, years of education increase one year the odds of adopting biogas will be increased $18.6 \%$, Walekhwa et al. (2009) indicated that in Uganda, education was negatively correlated with the biogas adoption. The reason might be as Walekhwa et al. (2009) explained that biogas technology is consumed by less educated people in rural area. It is clear that the average years of education of household heads in Bangladesh (8.75 years) is lower than in Uganda (11.34 years). Another thing is the marginal effect of household head's education is not linear and it will be changed in accordance with the level of education.

The second factor contributes to predict the potential adoption of biogas system is membership. The coefficient of the membership variable is 0.70 . It means that the odds of biogas adoption for household heads who are membership over those that are not membership is exponentiated of 0.70 or 2.00 . Or in term of percent change, the odds of adopting biogas for household heads who are memberships are 100\% higher than those for household heads are not memberships. If household heads joined any group they would tend to build the biogas system in their pig production compared to their counterparts who did not join any organizations. This is due to household head who became a member of any group they might have chance to access useful information of biogas system in manure management. Moreover, the marginal effect of this factor is 0.13 . It means that the probability of biogas adoption will be $13 \%$ higher for farmer who joined in some organizations compared to farmer who did not.

Large farm size in term of number of sows has a positively significant impact on the log odds of biogas adoption in manure management. It implies that the odds of biogas adoption for households who are large farms over the odds for households who are small farms is exponentiated of 1.42 or 4.12 . In other words, the odds for households who are large farms are $312 \%$ higher than the odds for households who are small farms. This is due to more sows is more manure are released so households consider whether or not construct a biogas plant. This results is similar to the results shown by Thien Thu et al. (2012). The authors indicated that non-adopted pig farms are enough animals to support a biogas production is one of the factor affecting on the farmer's decision to build or not build a biogas plant. In addition to, this finding is consistent to variety of studies which examined the biogas adoption in term of supplying energy including Kabir et al. (2013) and Walekhwa et al. (2009). Moreover, the marginal effect of large size is 0.24 which is shown that households having a large scale in pig production tend to adopt biogas technology with a 24\% higher probability compared to small household size. Also, this study found no difference in the probability of biogas adoption between medium and small farm size. All of these evidences show that farm size still contribute importantly to whether or not adopt biogas technology in manure management.

Out of three above factors, income is expected to be another crucial factor predict to the adoption of biogas technology in manure management. This variable also has an inverse-U shape like the education of the household head. The mean of total household annual income in study area which is 119.81 million VND is much less than the top of an inverse-U shape's income which is around 192.3 million VND. Thus the probability of biogas adoption is increasing with the household income or in other words, rich households are more likely to adopt biogas digester except for households with income is higher than 192.3 million VND because they tend to find better technologies to manage their manure in pig production. The same results are shown by Kabir et al. (2013), Mwirigi et al. (2009), and Qu et al. (2013). Their reasons explained for that is the high cost of constructing the biogas digesters.

\section{CONCLUSION AND IMPLICATIONS}

The main objective of this study is to investigate main factors affecting on the adoption of biogas technology in manure management in household pig production in Vietnam.

The first result of this study is found that there are differences in socioeconomic characteristics of household pig productions between biogas adoption group and biogas non-adoption group. On the one hand, the differences in household heads' characteristic including training, membership and education factors among two groups were found to be statistically significant. On the other hand, only farm size in the farm's characteristics between two groups has a significant difference, except for small farm size category.

The second results is to find out that the main factors affecting biogas adoption include education of household heads, membership factor, large farm size and income of household. All of these have positive impacts on the willingness of biogas adoption, except for some farmers with very high education and some households with high income, who might be seeking the more mod- 
ern technology in manure management.

Based on these evidences, to promote applying biogas system in pig production to contribute to reduce environmental pollution in livestock production the Vietnamese government should spread more information related to the advantages of biogas digester. Especially it is enhanced communicating channel among households. Moreover, farm size is a significant factor impact on biogas adoption but this study has not proved for differences in households between small size and medium size which are prominent farm size in pig production. Last but not least, financial programs should be offered to farmers, especially to low income households.

\section{ACKNOWLEDGEMENT}

We would like to thank to Mr. Nguyen Van Huyen, the head deputy of Tien Lu Agricultural and Rural Development Sector and Dr. Pham Van Hung who works as a lecturer of Vietnam National University of Agriculture and a coordinator of LPS/2010/2047 ACIAR project for supporting useful secondary information and organizing primary data collection.

\section{REFERENCES}

BPAHSV, Biogas Program for the Animal Husbandry Sector in Vietnam. 2015a Project location. Retrieved from http:// biogas.org.vn/vietnam/Gioi-thieu-du-an/Dia-ban-trien-khai. aspx

BPAHSV, Biogas Program for the Animal Husbandry Sector in Vietnam. 2015b Project overview. Retrieved from http:// biogas.org.vn/english/Introduction/Project-Overview.aspx

GSO, G. S. O. 2013 Statistical yearbook of Vietnam 2012. Hanoi: Statistical Publishing House

Gujarati, D. N., \& Handelshøyskolen, B. 2011 Econometrics by example. Palgrave Macmillan Hampshire, UK.

HYDARD, Hung Yen Department of Agricultural and Rural Development. 2010 Summary report on livestock development plan in 2015 and toward 2020. Hung Yen.

HYDARD, Hung Yen Department of Agricultural and Rural Development. 2012 General summary on revising the agricultural and rural development plan in the period 2010 - 2015 and toward 2020. Hung Yen.

Kabir, H., Yegbemey, R. N., \& Bauer, S. 2013 Factors determinant of biogas adoption in Bangladesh. Renewable and Sustainable Energy Reviews, 28: 881-889

Mwirigi, J. W., Makenzi, P. M., \& Ochola, W. O. 2009 Socioeconomic constraints to adoption and sustainability of biogas technology by farmers in Nakuru districts, Kenya. Energy for Sustainable Development, 13(2): 106-115. doi:http://dx.doi. org/10.1016/j.esd.2009.05.002

Qu, W., Tu, Q., \& Bluemling, B. 2013 Which factors are effective for farmers' biogas use?-Evidence from a large-scale survey in China. Energy Policy, 63: 26-33

Thien Thu, C. T., Cuong, P. H., Hang, L. T., Chao, N. V., Anh, L. X. Trach, N. X., \& Sommer, S. G. 2012 Manure management practices on biogas and non-biogas pig farms in developing countries - using livestock farms in Vietnam as an example. Journal of Cleaner Production, 27(0): 64-71. doi:http://dx. doi.org/10.1016/j.jclepro.2012.01.006

Tran, V. D., Ha, V. H., \& Huynh, T. L. H. 2009 Biogas user survey 2007-2008, Biogas Development Program For Livestock Sector in Vietnam 2007-2011. Hanoi: Biogas

Development Programme for Livestock Sector in Vietnam.

Vietnamese Prime Minister. 2008 The decision no. 10/2008/ QĐ-TTG about approval of Strategy to develop livestock until 2020, date 16/01/2008. Retrieved from http://vanban. chinhphu.vn/portal/page/portal/chinhphu/hethongvanban? class_id=1\&_page=318\&mode=detail\&document_id=75617

Vu, T., Tran, M., \& Dang, T. 2007 A survey of manure management on pig farms in northern Vietnam. Livestock Science, 112(3): 288-297

Walekhwa, P. N., Mugisha, J., \& Drake, L. 2009 Biogas energy from family-sized digesters in Uganda: Critical factors and policy implications. Energy Policy, 37(7): 2754-2762 